\title{
Adaptability and stability of corn hybrids in the off season across various agricultural regions in Brazil
}

A.P. Mijone ${ }^{1}$, A.P.O. Nogueira ${ }^{2}$, O.T. Hamawaki ${ }^{1}$, M.L. Maes ${ }^{1}$ and J.S. Pinsetta Junior ${ }^{3}$

${ }^{1}$ Universidade Federal de Uberlândia, Instituto de Ciências Agrárias, Uberlândia, MG, Brasil

${ }^{2}$ Universidade Federal de Uberlândia, Instituto de Biotecnologia, Uberlândia, MG, Brasil

${ }^{3}$ Universidade Estadual de São Paulo, Faculdade de Agricultura e

Ciências Veterinárias, Jaboticabal, SP, Brasil

Corresponding author: A.P. Mijone

E-mail: ana.mijone@gmail.com

Genet. Mol. Res. 18 (3): gmr18193

Received October 29, 2019

Accepted April 08, 2019

Published July 19, 2019

DOI http://dx.doi.org/10.4238/gmr18193

ABSTRACT. We evaluated how genetic $x$ environment ( $G \times E$ ) interactions affect grain productivity in corn hybrids grown in traditional and non-traditional environments in the off or "second" season. Adaptability and stability of the hybrids was examined by parametric, nonparametric and multivariate methods. In 2016, 24 hybrids were evaluated in seven environments, in 2017, 13 hybrids were evaluated in six environments. The environments were located between the regions of Southwestern and Southeast Goiás state; Triângulo Mineiro and Alto Paranaíba, in the western and northwestern regions of Minas Gerais state. In all trials, complete randomized blocks were adopted, and grain productivity was determined. The statistical analyses were performed with two different softwares: Estabilidade and Genes. It was observed that in both seasons, the locals considered as traditional corn cultivation in the off season Jataí-GO and Montividiu-GO gave 
the highest yields, with average yields higher than national averages, producing $3859 \mathrm{~kg} \cdot \mathrm{ha}^{-1}$ in 2016 and $5562 \mathrm{~kg} \cdot \mathrm{ha}^{-1}$ in 2017. The methods of Eberhart and Russell, Lin and Binns modified by Carneiro, Centroid and AMMI gave similar results in the rankings of the adaptation and stability of the hybrids. We concluded that the $\mathrm{G} \times \mathrm{E}$ interaction for grain productivity of corn hybrids grown in the off-season is complex in nature.

Key words: Zea mays; Interaction G x E; Adaptation

\section{INTRODUCTION}

Corn (Zea mays) due to its use for human and animal consumption and as raw material for industry is a major grain produced throughout the world (Moraes and Brito, 2011). It is grown throughout much of Brazil with various different production systems (Farinelli et al., 2003). Corn cultivation occurs practically throughout the country and production occurs at different periods of the year (agricultural crops) depending on the region (IBGE, 2015). The first crop or summer crop is grown mainly between September and March, while the second harvest in the off or "second" season is grown mostly between the months of January and May (Figueiredo et al., 2014).

The Cerrado is a Brazilian biome with immense social and environmental relevance. It stands out for its biodiversity and for being recognized as an agricultural expansion area. The increasing expansion of off season cropping in the States of Goiás and Minas Gerais is explained by the existence of suitable areas for crop cultivation during the off season; these areas are currently listed in new versions of published agricultural zoning (Embrapa, 2015).

Analyzing historical data, we observe that corn production in the off season was first recorded in the 1980s. In recent years, the off season is becoming more relevant (Landau et al., 2012) and it is possible to identify producers and traditional regions in the choice of summer crop soybean and corn as off season alternatives.

As soybean has become the main crop in many regions of the country due to its economic relevance, there has been a decrease in the area planted with summer corn, while the off season corn crop area has increased. In 2010/11, the area planted with corn crops in the off season exceeded the area planted in the summer; 2017/18 harvest estimates showed that off season corn crops were about two times larger than the summer harvest and accounted for $72.6 \%$ of total off season cereal crops cultivated in Brazil. National production of off season 2018 was estimated at more than 58 million tons, with an average productivity of $5029 \mathrm{~kg} \cdot \mathrm{ha}^{-1}$, a value very close to the national average productivity for the cultivation of summer corn (CONAB, 2017).

Off season corn is developed in a non-irrigated system, and it is usually cultivated after early-cycle soybeans. The adoption of the no-tillage system in soybean straw, allows a reduction of the time between the harvest of the summer crop and sowing of the off season corn (Tsunechiro and Godoy, 2001); however, yield and production are strongly dependent on weather conditions. 
The edaphoclimatic conditions of cultivation in the off season and summer vary considerably, but the vast majority of cultivars planted in the first harvest are also recommended for off season since corn breeding programs for off season are newer and less developed than those for summer corn breeding programs, and many cultivars from the breeding programs of the summer harvest show good performance and adaptation in the off season (Figueiredo et al., 2014). According to Fritsche-Neto et al. (2010) the success of a cultivar in the market is associated with high productive performance and the agronomic characteristics.

\section{MATERIAL AND METHODS}

The experiments were carried out in off season production environments in 2016 and 2017 in the southwest Goiás region, in representative sites for a traditional region (TRAD) in the cultivation of off season corn and in the southeast regions of Goiás, Triângulo Mineiro region, Alto Paranaíba region and northwest of Minas Gerais state, in representative sites for a non-traditional region (NTRAD) in the cultivation of off season corn (Table 1).

Table 1. Environments, states, medium altitudes (m), type and year off season corn.

\begin{tabular}{|c|c|c|c|c|c|c|}
\hline \# & Environment & State Latitude & Longitude & Altitude (m) & Type & Year \\
\hline$\overline{\mathrm{A} 1}$ & Araguari & MG $\quad-18.6459014$ & -48.1979841 & 890 & NTRAD & 2016 \\
\hline $\mathrm{A} 2$ & Catalão & GO $\quad-18.1661075$ & -47.9444777 & 835 & NTRAD & 2016 \\
\hline A3 & Indianopólis & MG -19.0380618 & -47.9178625 & 971 & NTRAD & 2016 \\
\hline A4 & Jataí & GO -17.8796049 & -51.7206735 & 867 & TRAD & 2016 \\
\hline A5 & Montividiu & GO $\quad-17.4494387$ & -51.1760652 & 897 & TRAD & 2016 \\
\hline A6 & Santana de Patos & MG -18.832624 & -46.5939409 & 851 & NTRAD & 2016 \\
\hline A7 & Uberlândia & MG $\quad-18.9127534$ & -48.275484 & 863 & NTRAD & 2016 \\
\hline A1 & Catalão & GO $\quad-18.1661075$ & -47.9444777 & 835 & NTRAD & 2017 \\
\hline $\mathrm{A} 2$ & Jataí & GO $\quad-17.8796049$ & -51.7206735 & 867 & TRAD & 2017 \\
\hline A3 & Montividiu & GO $\quad-17.4494387$ & -51.1760652 & 897 & TRAD & 2017 \\
\hline A4 & Patos de Minas & MG $\quad-18.5872582$ & -46.5146749 & 842 & NTRAD & 2017 \\
\hline A5 & Uberlândia & MG $\quad-18.9127534$ & -48.275484 & 863 & NTRAD & 2017 \\
\hline A6 & Unaí & MG $\quad-16.3596675$ & -46.902586 & 946 & NTRAD & 2017 \\
\hline
\end{tabular}

NTRAD: Non-traditional; TRAD: Traditional

The hybrids evaluated in the harvests are listed in Table 2. A randomized complete block design with two replications was adopted. Each plot consisted of four rows of corn plants with $8.20 \mathrm{~m}$ long, spaced at $0.5 \mathrm{~m}$, and the two central lines considered a useful plot.

The sowing was mechanized, in no-tillage system without soil development and sowing dates are within the main planting window in each region. The plant stand ranged from 50,000 to 65,000 plants ha ${ }^{-1}$. The cultural tracts were performed according to the recommendation for the corn crop. The control of weed and pest plants was carried out through pre-emergent herbicide, post-emergence and insecticides application so that the corn crop could develop without interference. 
Table 2. Corn hybrids sown in the experiments of off season in the years 2016 and 2017.

\begin{tabular}{rllrll}
\hline$\#$ & Hybrids & Off season & $\#$ & Hybrids & Year \\
\hline 1 & 3400RR2 & 2016 & 1 & AG8677PRO3 & 2017 \\
2 & AG7088PRO3 & 2016 & 2 & AG8690PRO3 & 2017 \\
3 & AG8070PRO3 & 2016 & 3 & AG9050PRO3 & 2017 \\
4 & AG8677PRO3 & 2016 & 4 & AS1555PRO3 & 2017 \\
5 & AG8700PRO3 & 2016 & 5 & AS1633PRO3 & 2017 \\
6 & AS1581PRO & 2016 & 6 & AS1735PRO3 & 2017 \\
7 & AS1656PRO3 & 2016 & 7 & AS1757PRO3 & 2017 \\
8 & AS1777PRO3 & 2016 & 8 & AS1780PRO3 & 2017 \\
9 & DAS2B512PW & 2016 & 9 & DKB290PRO3 & 2017 \\
10 & DAS2B610PW & 2016 & 10 & DKB310PRO3 & 2017 \\
11 & DAS2B688PW & 2016 & 11 & DKB335PRO3 & 2017 \\
12 & DAS2B810PW & 2016 & 12 & DKB390PRO3 & 2017 \\
13 & DKB290PRO3 & 2016 & 13 & H5 & \\
14 & DKB310PRO3 & 2016 & & & \\
15 & DKB390PRO2 & 2016 & & & \\
16 & DKB390PRO3 & 2016 & & & \\
17 & H1 & 2016 & & & \\
18 & H2 & 2016 & & & \\
19 & H3 & 2016 & & & \\
20 & H4 & 2016 & & & \\
21 & MG652PW & 2016 & & & \\
22 & P30F53YHR & 2016 & & & \\
23 & P3646LEP & 2016 & & & \\
24 & RIB9110PRO & 2016 & & & \\
\hline
\end{tabular}

Grain yield was determined in each plot, and corrected for grain moisture as shown in the equation below, being then extrapolated to $\mathrm{kg} \cdot \mathrm{ha}^{-1}$ :

$$
\mathrm{PF}=\mathrm{PI} \frac{100-\mathrm{UI}}{100-\mathrm{UF}}
$$

where:

PF: corrected final weight of the sample;

PI: initial sample weight;

UI: initial moisture sample;

UF: final moisture sample (13\%).

Data were subjected to individual analysis of variance according to the model:

$$
Y_{i j k}=\mu+B_{j}+G_{i} B_{j}+\varepsilon_{i j k}
$$

where:

$\mu$ : average mean;

$\mathrm{B}_{\mathrm{j}}$ : plot $\mathrm{j}$ effect;

$\mathrm{G}_{\mathrm{i}}$ : hybrid i effect;

$\varepsilon_{\mathrm{ijk}}$ : random error.

In each crop, after the analysis of individual variance, the ratio between the largest and lowest mean square of the residue was analyzed to test the homogeneity of the residual variances (Ramalho et al., 2012) and the degrees of freedom adjusted to carry out a joint analysis of variance (Cruz et al., 2012).

In the joint variance analysis, fixed effects were adopted for hybrids and cultivation sites in the following model: 


$$
\mathrm{Y}_{\mathrm{ijk}}=\mu+\mathrm{B} / \mathrm{A}_{\mathrm{jk}}+\mathrm{G}_{\mathrm{i}}+\mathrm{A}_{\mathrm{j}}+\mathrm{GA}_{\mathrm{ij}}+\varepsilon_{\mathrm{ijk}}
$$

where:

$\mu$ : average mean;

$\mathrm{B} / \mathrm{A}_{\mathrm{jk}}$ : effect of plot $\mathrm{k}$ in environment $\mathrm{j}$;

$\mathrm{G}_{\mathrm{i}}$ : hybrid i effect;

$\mathrm{A}_{\mathrm{j}}$ : environment $\mathrm{j}$ effect;

$\mathrm{GA}_{\mathrm{ij}}$ : interaction genotype-environment effect;

$\varepsilon_{\mathrm{ijk}}$ : random error.

Based on data from the analysis of the joint variance, the genotypic determination coefficient $\left(\mathrm{H}^{2}\right)$ was estimated, given by:

$$
\begin{gathered}
\mathrm{H}^{2}=\frac{\widehat{\emptyset}_{\mathrm{g}}}{\mathrm{QMG} / \mathrm{r}} \\
\widehat{\emptyset}_{\mathrm{g}}=\frac{(\mathrm{QMG}-\mathrm{QMR})}{\mathrm{r}}
\end{gathered}
$$

where:

$\mathrm{H}^{2}$ : coefficient of genotypic determination;

$\widehat{\emptyset}_{g}$ : component genetic squared;

QMG: average square of genotypes;

QMR: average square of residue;

r: replicates number.

The study of the interaction $G \times$ E was performed by decomposition in a complex part between pairs of environments, as described by Cruz and Castoldi (1991), by the estimator:

$$
\mathrm{C}=\sqrt{(1-\mathrm{r})^{3}} \sqrt{\mathrm{Q}_{1} \mathrm{Q}_{2}}
$$

In which, $\mathrm{Q}_{1}$ and $\mathrm{Q}_{2}$ correspond to the average squares of the genotypes in environments 1 and 2, respectively, and $\mathrm{r}$ the correlation between the means of the genotypes in both environments.

Once the interaction $G \times E$ was detected, the analysis of the phenotypic adaptability and stability was performed by the methods of Eberhart and Russel (1966), Lin and Binns (1988) Modified by Carneiro (1998), Centroid (Rocha et al., 2005) and AMMI (Zobel et al., 1988 ).

The analyses were performed using the computational program in Genetics and Statistics (GENES) (Cruz, 1997), and Estabilidade (UFLA, 2000).

\section{RESULTS}

It was observed in the analyses of individual variances for the year 2016 (Table 3) and for the year 2017 (Table 4) the opportunity to select hybrids with productive potential in most off season planting sites, whether these were traditional or nontraditional sites. 
Table 3. Average productivity of environments, average squares, coefficient of variation and genotypic determination coefficient obtained in the evaluation of 24 genotypes of off season corn cultivated in seven environments in 2016.

\begin{tabular}{|c|c|c|c|c|c|}
\hline$\#$ & Environment & QMG $^{1}$ & QMR $^{1}$ & $\mathrm{CV}(\%)^{1}$ & Yield $\left(\mathrm{kg} \mathrm{ha}^{-1}\right)$ \\
\hline A1 & Araguari-MG & $1117430.10^{* *}$ & 135321 & 10.005 & 3676.42 \\
\hline A2 & Catalão-GO & $890991.89 * *$ & 49331.9 & 9.35 & 2376.24 \\
\hline A3 & Indianopólis-MG & $2411558.20^{* *}$ & 242787 & 15.24 & 3233.09 \\
\hline A4 & Jataí-GO & $732573.60^{\mathrm{ns}}$ & 184623 & 6.39 & 6723.66 \\
\hline A5 & Montividiu-GO & $2436535.20 * *$ & 316483 & 9.6 & 5861.08 \\
\hline A6 & Santana de Patos-MG & $1197852.73^{\mathrm{ns}}$ & 394703 & 19.51 & 3220.45 \\
\hline A7 & Uberlândia-MG & $461168.02^{\mathrm{ns}}$ & 346677 & 11.06 & 5325.27 \\
\hline
\end{tabular}

NS: not significant; * and **: significant at $5 \%$ and $1 \%$, respectively, by the F test; QMG: Average square of genotypes; QMR: Average square of error; CV (\%): coefficient of variation; ${ }^{1}$ results obtained by individual analysis of variance.

Table 4. Average productivity of environments, average squares, coefficient of variation and genotypic determination coefficient obtained in the evaluation of 13 genotypes of off season corn cultivated in six environments in 2017.

\begin{tabular}{|c|c|c|c|c|c|}
\hline$\#$ & Environment & QMG $^{1}$ & $\mathbf{Q M R}^{1}$ & $\mathrm{CV}(\%)^{1}$ & Yield $\left(\mathrm{kg} \mathrm{ha}^{-1}\right)$ \\
\hline A1 & Catalão-GO & $435376.62 * *$ & 113218.87 & 4.76 & 7062.06 \\
\hline $\begin{array}{l}\text { A2 } \\
\text { A3 }\end{array}$ & $\begin{array}{l}\text { Jataí-GO } \\
\text { Montividiu-GO }\end{array}$ & $\begin{array}{l}625832.52 * * \\
1261886.82^{\text {ns }}\end{array}$ & $\begin{array}{c}73806.35 \\
1193793.1\end{array}$ & $\begin{array}{r}3.43 \\
10.41\end{array}$ & $\begin{array}{r}7911.94 \\
10496.62\end{array}$ \\
\hline A4 & Patos de Minas-MG & $1260766.12 * *$ & 269094.09 & $\begin{array}{r}10.41 \\
7.11\end{array}$ & 7300.31 \\
\hline A5 & Uberlândia-MG & $3461598.21 * *$ & 317906.41 & 9.81 & 5746.14 \\
\hline A6 & Unaí-MG & $61513.22 * *$ & 194862.86 & 9.51 & 4642.15 \\
\hline
\end{tabular}

NS: not significant; $*$ and **: significant at $5 \%$ and $1 \%$, respectively, by the F test; QMG: Average square of genotypes; QMR: Average square of error; CV (\%): coefficient of variation; ${ }^{1}$ results obtained by individual analysis of variance.

For the year 2016, the analyzed sites presented coefficient of variation (CV) between 6.39 and $19.51 \%$ (Table 3), while for the year 2017 the CV ranged from 3.43 to $10.41 \%$.

Jataí-GO and Montividiu-GO, places classified as traditional in the planting of off season corn, were the sites that presented the highest productive potential in the two evaluated off seasons (Tables 3 and 4). The average yield of the experiments in these locations was similar to the values found by Silva et al. (2015) for the same region in the off season of 2013.

The ratios between the largest and the smallest mean square of the residue of the individual variance analyses for the years 2016 and 2017 (Tables 3 and 4) were 8 and 16.17, respectively. Therefore, to proceed with the joint analysis, the degree of freedom adjustments were made as suggested by Cruz et al. (2012).

The summary of the joint analysis of variance is found in Table 5 and Table 6 , where it is noted significant effects for interaction between genotypes and environments at $1 \%$ probability level by F test. Silva et al. (2014) and Faria (2016) also reported significant occurrence of $\mathrm{G} \times \mathrm{E}$ interaction for grain yield. 
Table 5. Analysis of variance combined for grain yield $\left(\mathrm{kg}_{\mathrm{g}} \mathrm{ha}^{-1}\right)$ evaluated in 24 genotypes of off season corn cultivated in seven environments in 2016.

\begin{tabular}{lcc}
\hline Sources of variation Variação & Degrees of freedom & Mean square Médio \\
\hline Plot/environment & 7 & 1328592.18 \\
Genotype $(\mathrm{G})$ & 23 & $2992026.99 * *$ \\
Environment $(\mathrm{E})$ & 6 & $125931384.78^{*} *$ \\
Interaction G x E & 116 & $1240430.20 * *$ \\
Error & 131 & 293193.19 \\
Mean & & 4345.17 \\
$\mathrm{CV}(\%)$ & & 12.46 \\
$\mathrm{H}^{2}$ & & 58.54 \\
\hline$* *$ : Significant to 1\%, by F test; CV (\%): coefficient of variation; $\mathrm{H}^{2}$ : Genotypic determination coefficient.
\end{tabular}

Table 6. Analysis of variance combined for grain yield $\left(\mathrm{kg}_{\text {.ha }}{ }^{-1}\right)$ evaluated in 13 genotypes of off season corn cultivated in six environments in 2017.

\begin{tabular}{lcc}
\hline Sources of variation & Degrees of freedom & Mean square \\
\hline Plot/environment & 6 & 1608116.55 \\
Genotype (G) & 12 & $2698455.06^{\mathrm{ns}}$ \\
Environment (E) & 5 & $104310470.25^{* *}$ \\
Interaction G x E & 32 & $1860800.79 * *$ \\
Error & 34 & 763299.42 \\
Mean & & 7193.20 \\
CV $(\%)$ & 12.14 \\
$\mathrm{H}^{2}$ & & 31.04 \\
\hline$*$ : Significant to $1 \%$, by F test; CV (\%): coefficient of variation; $\mathrm{H}^{2}$ : Genotypic determination coefficient.
\end{tabular}

According to Table 7 and Table 8, it was observed that, in the two years, the interaction $\mathrm{G} \times \mathrm{E}$ was predominantly of a complex nature, because the decomposition of the interaction G x E, partly complex, by the method of Cruz and Castoldi (1991) showed that among the 21 pairs of environments was in the year 2016 and the 15 pairs of environments evaluated in 2017, only 3 environments in each year had decomposition of the interaction lower than $50 \%$, indicating predominance of interaction of the simple type, and all other interactions were of a complex nature, demonstrating the importance of conducting adaptability and stability studies. Martinelli (2013) also verified interaction G x E Complex in the tests performed with corn in the off seasons 2012 and 2013.

Table 7. Estimation of the complex part of the decomposition of the interaction $\mathrm{G} \times \mathrm{E}(\%)$ by the Cruz and Castoldi Method (1991) (below the diagonal) and the classification of the interaction between simple and complex (above the diagonal) in the analysis of 24 genotypes of off season corn cultivated in 7 Environments at 2016.

\begin{tabular}{llllllll}
\hline Environments & E 1 & E 2 & E 3 & E 4 & E 5 & E 6 & E 7 \\
\hline E 1 & - & C & S & C & C & C & C \\
E 2 & 57.22 & - & S & C & C & C & C \\
E 3 & 40.64 & 36.60 & - & C & C & C & S \\
E 4 & 57.71 & 63.53 & 61.72 & - & C & C & C \\
E 5 & 112.92 & 95.88 & 105.60 & 94.58 & - & C & C \\
E 6 & 83.04 & 72.56 & 72.68 & 92.67 & 71.43 & - & C \\
E 7 & 79.19 & 86.33 & 49.82 & 92.64 & 80.39 & 81.00 & - \\
\hline
\end{tabular}

Environments: E1 (Araguari-MG) E2 (Catalão-GO), E3 (Indianopólis-MG), E4 (Jataí-GO), E5 (Monitividiu-GO), E6 (Santana de Patos-MG), E7 (Uberlândia-MG); C: Complex interaction; S: Simple interaction. 
Table 8. Estimation of the complex part of the decomposition of the interaction $\mathrm{G} x \mathrm{E}$ (\%) by the Cruz and Castoldi Method (1991) (below the diagonal) and the classification of the interaction between simple and complex (above the diagonal) in the analysis of 13 genotypes of off season corn cultivated in 6 Environments at 2017.

\begin{tabular}{|c|c|c|c|c|c|c|}
\hline Environments & E 1 & E 2 & E 3 & E 4 & E 5 & E 6 \\
\hline E 1 & - & $\mathrm{C}$ & $\mathrm{C}$ & $\mathrm{S}$ & $\mathrm{S}$ & $\mathrm{C}$ \\
\hline E 2 & 94.34 & - & $\mathrm{C}$ & $\mathrm{C}$ & $\mathrm{S}$ & $\mathrm{C}$ \\
\hline E 3 & 88.50 & 87.78 & - & $\mathrm{C}$ & $\mathrm{C}$ & $\mathrm{C}$ \\
\hline E 4 & 31.57 & 67.26 & 109.61 & - & $\mathrm{C}$ & $\mathrm{C}$ \\
\hline E 5 & 19.37 & 48.27 & 88.58 & 55.35 & - & $\mathrm{C}$ \\
\hline E 6 & 67.53 & 88.07 & 90.99 & 72.83 & 61.79 & - \\
\hline
\end{tabular}

Environments: E1 (Catalan-GO), E2 (Jataí-GO), E3 (Montividiu-GO), E4 (Patos de Minas-MG), E5 (Uberlândia-MG), E6 (Unaí-MG), C: complex interaction; S: Simple interaction.

In Tables 9 and 10, the environmental indexes (EI) and the classification of the studied environments are presented for the years 2016 and 2017, respectively. The EI is obtained by the difference between the means of tested genotypes in such environment and the average mean. It is observed that in the year 2016, $43 \%$ of the sites were classified as favorable to the planting of off season corn, while for the year 2017 this index was $50 \%$. In the two years of testing, $100 \%$ of the environments of the region considered to be traditional for off season planting were evaluated as favorable, while most of the sites in the non-traditional regions were classified as unfavorable.

Table 9. Environmental index (EI), in the analysis of 24 genotypes of off season corn cultivated in 7 environments in 2016.

\begin{tabular}{llcl}
\hline Environments & Average $\left(\mathbf{k g . h a}^{-\mathbf{1}}\right)$ & EI $\left(\mathbf{k g . h a} \mathbf{- 1}^{\mathbf{1}}\right)$ & Classification \\
\hline Araguari-MG & 3676.42 & -668.75 & Unfavorable \\
Catalão-GO & 2376.24 & -1968.93 & Unfavorable \\
Indianopólis-MG & 3233.09 & -1112.08 & Unfavorable \\
Jataí-GO & 6723.66 & 2378.49 & Favorable \\
Montividiu-GO & 5861.08 & 1515.91 & Favorable \\
Santana de Patos-MG & 3220.45 & -1124.73 & Unfavorable \\
Uberlândia-MG & 5325.27 & 980.09 & Favorable \\
\hline
\end{tabular}

Table 10. Environmental index (EI), in the analysis of 13 genotypes of off season corn cultivated in 6 environments in 2017.

\begin{tabular}{lccl}
\hline Environments & Average $\left(\mathbf{k g}^{-h a}{ }^{-1}\right)$ & EI $\left(\mathbf{k g . h a} \mathbf{~}^{-\mathbf{1}}\right)$ & Classification \\
\hline Catalão-GO & 7062.06 & -131.14 & Unfavorable \\
Jataí-GO & 7911.94 & 718.74 & Favorable \\
Montividiu-GO & 10496.62 & 3303.42 & Favorable \\
Patos de Minas-MG & 7300.61 & 107.10 & Favorable \\
Uberlândia-MG & 5746.14 & -1447.06 & Unfavorable \\
Unaí-MG & 4642.15 & -2551.06 & Unfavorable \\
\hline
\end{tabular}

Table 11 shows that 13 out of 24 genotypes tested in 2016 are of broad adaptation, but only four of these have high stability, while for the year 2017, 9 out of 
13 genotypes tested (Table 12) are of wide adaptation and 7 out of 9 have high stability. Using the Eberhart and Russel Method (1966) for the analysis of off season hybrids, Faria (2016) also found that most hybrids showed high predictability of behavior and wide adaptability.

Table 11. Grain yield and stability and adaptability parameters by the methods of Eberhart and Russel (1966) and Lin and Binns (1988) Modified by Carneiro (1998), in 24 off season corn genotypes cultivated in seven environments in 2016.

\begin{tabular}{|c|c|c|c|c|c|c|c|}
\hline \multirow[t]{2}{*}{ Genotypes } & \multirow[t]{2}{*}{ Yield (kg ha $\left.{ }^{-1}\right)$} & \multicolumn{3}{|c|}{ Eberhart \& Russel (1966) } & \multicolumn{3}{|c|}{$\begin{array}{l}\text { Lin } 7 \text { Binns (1988) modified by Carneiro } \\
\text { (1998) }\end{array}$} \\
\hline & & $\mathbf{B}_{1 \mathrm{i}}$ & $\mathbf{S}^{2} \mathbf{d i}$ & $\mathbf{R}^{2}(\%)$ & Pi general & Pi favorable & Pi unfavorable \\
\hline 3400RR2 & 4837.79 & $0.81 *$ & $98297.25^{\mathrm{ns}}$ & 90.53 & 752913.33 & 1276572.24 & 360169.15 \\
\hline AG7088PRO3 & 4635.31 & $0.81 *$ & $81129.06^{\text {ns }}$ & 91.06 & 975452.40 & 1458751.41 & 612978.15 \\
\hline AG8070PRO3 & 5317.95 & $0.57 * *$ & $95850.59^{\mathrm{ns}}$ & 82.77 & 688573.39 & 1604845.98 & 1368.95 \\
\hline AG8677PRO3 & 4656.2 & $1.06^{\mathrm{ns}}$ & $292185.77^{++}$ & 89.65 & 890180.87 & 805279.92 & 953856.59 \\
\hline AG8700PRO3 & 4608.46 & $1.07^{\mathrm{ns}}$ & $53526.91^{\mathrm{ns}}$ & 95.43 & 903203.24 & 732665.73 & 1031106.38 \\
\hline AS1581PRO & 3839.83 & $1.22 *$ & $163197.76^{+}$ & 94.28 & 2371961.77 & 1723037.48 & 2858654.99 \\
\hline AS1656PRO3 & 3902.77 & $0.94^{\mathrm{ns}}$ & $343909.92^{++}$ & 85.7 & 1985199.89 & 1917928.40 & 2035653.51 \\
\hline AS1777PRO3 & 4780.82 & $0.81 *$ & $400247.39^{++}$ & 79.71 & 1108852.48 & 1995131.65 & 444143.1 \\
\hline DAS2B512PW & 4828.59 & $0.96^{\mathrm{ns}}$ & $39595.59^{\mathrm{ns}}$ & 94.8 & 744785.07 & 941099.97 & 597548.89 \\
\hline DAS2B610PW & 4647.16 & $1.01^{\mathrm{ns}}$ & $223572.28^{+}$ & 90.34 & 1108595.60 & 1275995.32 & 983045.81 \\
\hline DAS2B688PW & 3775.31 & $0.96^{\mathrm{ns}}$ & $280575.87^{++}$ & 87.93 & 2563423.44 & 2566784.01 & 2560903.01 \\
\hline DAS2B810PW & 3969.18 & $0.95^{\mathrm{ns}}$ & $446345.56^{++}$ & 83.48 & 2305220.90 & 2705499.62 & 2005011.87 \\
\hline DKB290PRO3 & 4483.84 & $0.81 *$ & $34158.41^{\mathrm{ns}}$ & 93.14 & 1309738.04 & 2027084.66 & 771728.08 \\
\hline DKB310PRO3 & 4121.51 & $1.25^{* *}$ & $-83537.77^{\mathrm{ns}}$ & 99.28 & 1737467.63 & 970629.28 & 2312596.4 \\
\hline DKB390PRO2 & 3889.03 & $1.17^{\mathrm{ns}}$ & $455508.91^{++}$ & 88.17 & 2385011.41 & 1524632.72 & 3030295.43 \\
\hline DKB390PRO3 & 3525.23 & $1.16^{\mathrm{ns}}$ & $266256.67^{++}$ & 91.59 & 3054931.56 & 2105831.35 & 3766756.72 \\
\hline $\mathrm{H} 1$ & 4011.25 & $0.78^{*}$ & $2196444.32^{++}$ & 45.01 & 3298097.19 & 5446369.14 & 1686893.23 \\
\hline $\mathrm{H} 2$ & 4663.26 & $0.77 * *$ & $796134.03^{++}$ & 67.01 & 1625369.38 & 3163708.21 & 471615.25 \\
\hline H3 & 3988.98 & $1.35^{* *}$ & $663693.02^{++}$ & 88.00 & 2111070.38 & 699060.20 & 3170078.01 \\
\hline $\mathrm{H} 4$ & 4066.8 & $1.35^{* * *}$ & $-48402.64^{\mathrm{ns}}$ & 98.77 & 2074819.96 & 1193388.54 & 2735893.53 \\
\hline MG652PW & 4725.48 & $1.04^{\mathrm{ns}}$ & $-2453.19^{\mathrm{ns}}$ & 96.7 & 744861.03 & 615514.54 & 841870.91 \\
\hline P30F53YHR & 4100.48 & $0.92^{\mathrm{ns}}$ & $590712.44^{++}$ & 78.83 & 1706610.80 & 1515332.37 & 1850069.62 \\
\hline P3646LEP & 3980.48 & $1.17^{\mathrm{ns}}$ & $65977.51^{\mathrm{ns}}$ & 95.85 & 2031496.53 & 1421688.05 & 2488852.89 \\
\hline RIB9110PRO & 4928.45 & $1.08^{\mathrm{ns}}$ & $1255089.11^{++}$ & 72.92 & 656131.63 & 185392.01 & 1009186.34 \\
\hline
\end{tabular}

NS: not significant; $*$ and $* *$ : significant at $5 \%$ and $1 \%$, by T. NS Test: not significant; + and ++ : Significant at $5 \%$ and $1 \%$ by $\mathrm{F}$ test; $\mathrm{B}_{1} \mathrm{i}$ : Adaptability parameter; $\mathrm{S}^{2}$ di: variance of regression deviations; $\mathrm{R}^{2}$ : Coefficient of regression determination.

The non-parametric method of Lin and Binns (1988) Modified by Carneiro (1998) allows analyzing the adaptation and stability of the genotypes by only one parameter (Pi), as shown in Tables 11 and 12. Considering the lowest estimates of general Pi, for the Year 2016 (Table 11) it was observed that among the 5 hybrids with higher productivity and general adaptation, RIB9110PRO and MG652PW has specific adaptation to favorable environments and AG8070PRO3, 3400RR2 and DAS2B512PW specific adaptation to unfavorable environments. Regarding the year 2017 (Table 12) among the 5 hybrids with higher productivity and general adaptation, the hybrids DKB335PRO3, AS1633PRO3, AS1735PRO3 and AS1557PRO3 also classified among the best in the specific adaptation to favorable environments and in the adaptation specific to favorable environments. 
The non-parametric method of Lin and Binns (1988) Modified by Carneiro (1998) allows analyzing the adaptation and stability of the genotypes by only one parameter $(\mathrm{Pi})$, as shown in Tables 11 and 12. Considering the lowest estimates of general Pi, for the Year 2016 (Table 11) it was observed that among the 5 hybrids with higher productivity and general adaptation, RIB9110PRO and MG652PW has specific adaptation to favorable environments and AG8070PRO3, 3400RR2 and DAS2B512PW specific adaptation to unfavorable environments. Regarding the year 2017 (Table 12) among the 5 hybrids with higher productivity and general adaptation, the hybrids DKB335PRO3, AS1633PRO3, AS1735PRO3 and AS1557PRO3 also classified among the best in the specific adaptation to favorable environments and in the adaptation specific to favorable environments.

The hybrid that presented the highest grain yield was the RIB9110PRO in the Montividiu-GO environment, reaching $8470 \mathrm{~kg} \mathrm{ha}^{-1}$ in the off season of 2016, while in the production environment of Araguari-MG is among the hybrids that produced the least. This fact indicates that there is a complex type interaction between hybrids and production environments. (Table 13). This result is justified by the fact that Montividiu is a traditional region in the cultivation of off season corn, which indicates that there is historically the presence of edaphoclimatic conditions and the use of technologies that favor the best performance of hybrids. On the other hand, in the Araguari production environment, which is considered a non-traditional region for the cultivation of the off season corn, we have a lower productivity that is the result of a less favorable production environment for genotype expression.

Table 12. Grain yield and stability and adaptability parameters by the methods of Eberhart and Russel (1966) and Lin and Binns (1988) Modified by Carneiro (1998), in 13 off season corn genotypes cultivated in 6 environments in 2017.

\begin{tabular}{|c|c|c|c|c|c|c|c|}
\hline \multirow{2}{*}{ Genotypes } & \multirow{2}{*}{ Yield $\left(\mathrm{kg} \mathrm{ha}^{-1}\right)$} & \multicolumn{3}{|c|}{ Eberhart \& Russel (1966) } & \multicolumn{3}{|c|}{ Lin \& Binns (1988) modified by Carneiro (1998) } \\
\hline & & $\mathbf{B}_{1 \mathrm{i}}$ & $\mathbf{S}^{2} \mathbf{d i}$ & $\mathbf{R}^{2}(\%)$ & Pi general & Pi favorable & Pi unfavorable \\
\hline AG8677PRO3 & 6999.83 & $0.74 * *$ & $26624.39^{\mathrm{ns}}$ & 92.98 & 983810.00 & 1436981.30 & 530638.71 \\
\hline AG8690PRO3 & 6589.16 & $1.13^{\mathrm{ns}}$ & $-55524.87^{\text {ns }}$ & 98.09 & 1623223.91 & 1085202.12 & 2161245.69 \\
\hline AG9050PRO3 & 7231.25 & $0.70^{* * *}$ & $311395.41^{+}$ & 83.30 & 857513.01 & 1494987.21 & 220038.80 \\
\hline AS1555PRO3 & 6938.52 & $1.10^{\mathrm{ns}}$ & $218250.57^{\mathrm{ns}}$ & 93.85 & 1175117.29 & 1066828.02 & 1283406.55 \\
\hline AS1633PRO3 & 7755.53 & $0.93^{\text {ns }}$ & $-65817.46^{\mathrm{ns}}$ & 97.43 & 156188.71 & 228581.30 & 83796.13 \\
\hline AS1735PRO3 & 7826.94 & $0.92^{\mathrm{ns}}$ & $379437.28^{+}$ & 88.30 & 173203.03 & 229890.76 & 116515.31 \\
\hline AS1757PRO3 & 7477.22 & $0.91^{\mathrm{ns}}$ & $-104982.38^{\text {ns }}$ & 98.23 & 422861.05 & 502580.03 & 343142.07 \\
\hline AS1780PRO3 & 7363.74 & $1.22 *$ & $547011.72^{++}$ & 91.16 & 1007646.93 & 131584.42 & 1883709.44 \\
\hline DKB290PRO3 & 6874.52 & $1.16^{\mathrm{ns}}$ & $72711.44^{\mathrm{ns}}$ & 96.36 & 1251027.37 & 510506.78 & 1991547.96 \\
\hline DKB310PRO3 & 7093.27 & $1.27 * *$ & $552355.24^{++}$ & 91.67 & 846260.73 & 770398.23 & 922123.23 \\
\hline DKB335PRO3 & 7866.13 & $0.88^{\text {ns }}$ & $212628.70^{\text {ns }}$ & 90.82 & 119308.92 & 231588.63 & 7029.21 \\
\hline DKB390PRO3 & 6278.14 & $1.10^{\mathrm{ns}}$ & $907589.32^{++}$ & 84.89 & 2600631.04 & 1920053.79 & 3281208.30 \\
\hline H5 & 7217.40 & $0.94^{\mathrm{ns}}$ & $195276.34^{\mathrm{ns}}$ & 92.19 & 854462.47 & 594384.44 & 1114540.50 \\
\hline
\end{tabular}

NS: not significant; $*$ and $* *$ : significant at $5 \%$ and $1 \%$, by T. NS Test: not significant; + and ++ : Significant at $5 \%$ and $1 \%$ by $\mathrm{F}$ test; $\mathrm{B}_{1} \mathrm{i}$ : Adaptability parameter; $\mathrm{S}{ }^{2}$ di: variance of regression deviations; $\mathrm{R}^{2}$ : Coefficient of regression determination. 
Table 13. Average yield (kg.ha $\left.{ }^{-1}\right)$ of off season corn genotypes cultivated in 7 environments in 2016.

\begin{tabular}{|c|c|c|c|c|c|c|c|}
\hline \multirow[b]{2}{*}{ Genotypes } & \multicolumn{7}{|l|}{ Locations } \\
\hline & $\begin{array}{l}\text { Araguari- } \\
\text { MG }\end{array}$ & $\begin{array}{l}\text { Catalão- } \\
\text { GO }\end{array}$ & $\begin{array}{l}\text { Indianopólis- } \\
\text { MG }\end{array}$ & Jataí-GO & $\begin{array}{l}\text { Montividiu } \\
\text {-GO }\end{array}$ & $\begin{array}{l}\text { Santana de Patos- } \\
\text { MG }\end{array}$ & $\begin{array}{l}\text { Uberlândia- } \\
\text { MG }\end{array}$ \\
\hline 3400RR2 & $4539.41 \mathrm{Ca}$ & $2809.17 \mathrm{Da}$ & $4638.32 \mathrm{Ca}$ & 6991.96Aa & $6008.76 \mathrm{Bc}$ & 3761.44Db & $5115.48 \mathrm{Cb}$ \\
\hline AG7088PRO3 & $3922.98 \mathrm{Cb}$ & $2710.97 \mathrm{Da}$ & $3656.83 \mathrm{Cb}$ & 6703.21Aa & $5905.06 \mathrm{Ac}$ & $4537.68 \mathrm{Ca}$ & $5010.44 \mathrm{Bb}$ \\
\hline AG8070PRO3 & $5027.29 \mathrm{Ba}$ & $3994.78 \mathrm{Ca}$ & $4976.56 \mathrm{Ba}$ & $7255.81 \mathrm{Aa}$ & $5415.8 \mathrm{Bd}$ & $4766.53 \mathrm{Ba}$ & $5788.89 \mathrm{Ba}$ \\
\hline AG8677PRO3 & $3884.09 \mathrm{Bb}$ & $2635.85 \mathrm{Ca}$ & $3041.65 \mathrm{Cc}$ & 7274.29Aa & 6976.69Ab & 4071.44Ba & $4709.42 \mathrm{Bb}$ \\
\hline AG8700PRO3 & $3864.1 \mathrm{Cb}$ & $2587.22 \mathrm{Da}$ & $3071.05 \mathrm{Dc}$ & 7094.91Aa & $6784.51 \mathrm{Ab}$ & $3752.01 \mathrm{Cb}$ & $5105.47 \mathrm{Bb}$ \\
\hline AS1581PRO & $2836.6 \mathrm{Dc}$ & $2121.25 \mathrm{Db}$ & 1969.49Dd & $7135.73 \mathrm{Aa}$ & $5920.19 \mathrm{Bc}$ & 2519.74Dc & $4375.86 \mathrm{Cb}$ \\
\hline AS1656PRO3 & $3372.09 \mathrm{Cc}$ & $1444.94 \mathrm{Db}$ & $2900.54 \mathrm{Cc}$ & $5222.87 \mathrm{Bb}$ & $6303.92 \mathrm{Ac}$ & $3224.91 \mathrm{Cb}$ & $4850.13 \mathrm{Bb}$ \\
\hline AS1777PRO3 & $5131.94 \mathrm{Ba}$ & $2640.86 \mathrm{Da}$ & $4443.19 \mathrm{Ca}$ & $7259.84 \mathrm{Aa}$ & $5187.36 \mathrm{Bd}$ & $3568.37 \mathrm{Cb}$ & $5234.21 \mathrm{Bb}$ \\
\hline DAS2B512PW & $4418.16 \mathrm{Ca}$ & $2596.36 \mathrm{Da}$ & $4431.76 \mathrm{Ca}$ & 7087.15Aa & $6186.09 \mathrm{Bc}$ & $3345.78 \mathrm{Db}$ & $5734.86 \mathrm{Ba}$ \\
\hline DAS2B610PW & $3964.96 \mathrm{Cb}$ & $2528.95 \mathrm{Da}$ & $4410.44 \mathrm{Ca}$ & 7121.7Aa & $5733.05 \mathrm{Bc}$ & $2758.2 \mathrm{Dc}$ & $6012.81 \mathrm{Ba}$ \\
\hline DAS2B688PW & $3040.08 \mathrm{Cc}$ & $2198.63 \mathrm{Db}$ & 1621.93Dd & $6275.3 \mathrm{Ab}$ & $5043.64 \mathrm{Bd}$ & $3489.17 \mathrm{Cb}$ & $4758.43 \mathrm{Bb}$ \\
\hline DAS2B810PW & $3853.59 \mathrm{Cb}$ & $2341.03 \mathrm{Da}$ & $3501.29 \mathrm{Cb}$ & 6692.44Aa & 4734.88Bd & 1685.2Dd & $4975.88 \mathrm{Bb}$ \\
\hline DKB290PRO3 & $3919.18 \mathrm{Cb}$ & $3192.63 \mathrm{Ca}$ & $3696.26 \mathrm{Cb}$ & 6897.64Aa & $5170.51 \mathrm{Bd}$ & $3210.76 \mathrm{Cb}$ & $5299.92 \mathrm{Bb}$ \\
\hline DKB310PRO3 & $3123.29 \mathrm{Cc}$ & $1722.29 \mathrm{Db}$ & $2827.92 \mathrm{Cc}$ & $6882.51 \mathrm{Aa}$ & $6297.49 \mathrm{Ac}$ & $2602 \mathrm{Cc}$ & $5395.12 \mathrm{Bb}$ \\
\hline DKB390PRO2 & $2820.13 \mathrm{Bc}$ & $1639.76 \mathrm{Cb}$ & $1603.43 \mathrm{Cd}$ & $6081.98 \mathrm{Ab}$ & $5764.06 \mathrm{Ac}$ & $3361.64 \mathrm{Bb}$ & $5952.22 \mathrm{Aa}$ \\
\hline DKB390PRO3 & $2628.37 \mathrm{Bc}$ & $1268.74 \mathrm{Cb}$ & $1593.5 \mathrm{Cd}$ & $5569.57 \mathrm{Ab}$ & $5502.51 \mathrm{Ad}$ & $2532.74 \mathrm{Bc}$ & $5581.21 \mathrm{Aa}$ \\
\hline $\mathrm{H} 1$ & $4353.9 \mathrm{Ca}$ & 3169.17Da & $3446.82 \mathrm{Db}$ & 7380.9Aa & 2855.57Df & $1625.18 \mathrm{Ed}$ & $5247.24 \mathrm{Bb}$ \\
\hline $\mathrm{H} 2$ & $4446.73 \mathrm{Ba}$ & $2650.48 \mathrm{Ca}$ & $4240.72 \mathrm{Ba}$ & $7072.52 \mathrm{Aa}$ & $4124.93 \mathrm{Be}$ & $3789.38 \mathrm{Bb}$ & 6318.07Aa \\
\hline H3 & $2854.74 \mathrm{Cc}$ & $1952.39 \mathrm{Db}$ & 1493.09Dd & $6734.03 \mathrm{Aa}$ & $7377.22 \mathrm{Ab}$ & $2799.54 \mathrm{Cc}$ & $4711.87 \mathrm{Bb}$ \\
\hline $\mathrm{H} 4$ & $3224.29 \mathrm{Cc}$ & $1495.26 \mathrm{Db}$ & 2202.91Dd & 7247.69Aa & $5860.23 \mathrm{Bc}$ & $2691.13 \mathrm{Cc}$ & $5746.08 \mathrm{Ba}$ \\
\hline MG652PW & $3857.43 \mathrm{Cb}$ & $2661.12 \mathrm{Da}$ & $4014.85 \mathrm{Cb}$ & 6979.11Aa & $6722.93 \mathrm{Ab}$ & $3215.06 \mathrm{Db}$ & $5627.86 \mathrm{Ba}$ \\
\hline P30F53YHR & $2552.54 \mathrm{Dc}$ & $1929.42 \mathrm{Db}$ & $4061.9 \mathrm{Cb}$ & $5454.87 \mathrm{Bb}$ & $6389.13 \mathrm{Ac}$ & $3021.56 \mathrm{Dc}$ & $5293.96 \mathrm{Bb}$ \\
\hline P3646LEP & $3771.65 \mathrm{Cb}$ & $1561.61 \mathrm{Db}$ & 2042.32Dd & 6461.57Aa & $5930.65 \mathrm{Ac}$ & $2887.6 \mathrm{Cc}$ & $5207.99 \mathrm{Bb}$ \\
\hline RIB9110PRO & $2826.67 \mathrm{Dc}$ & 3176.97Da & $3707.55 \mathrm{Cb}$ & $6490.32 \mathrm{Ba}$ & $8470.86 \mathrm{Aa}$ & $4073.7 \mathrm{Ca}$ & $5753.08 \mathrm{Ba}$ \\
\hline
\end{tabular}

${ }^{1}$ averages followed by distinct letters, uppercase in the row and lowercase in the column, differ from each other by the Scott-Knott test at $5 \%$ probability.

In the off season of 2017, the hybrid AS1780PRO3 was the one that stood out in terms of productivity in the production environment of Montividiu-GO, reaching 11673 kg.ha ${ }^{-1}$ (Table 14). In this same crop, Montividiu presented the best yields for the majority of hybrids, as shown in Table 14.

Table 14. Average yield $\left(\mathrm{kg} \mathrm{ha}^{-1}\right)$ of off season corn genotypes cultivated in seven environments in 2017.

\begin{tabular}{lllclll}
\hline \multirow{2}{*}{ Genotypes } & Locations & \multicolumn{7}{l}{} \\
\cline { 2 - 7 } & Catalão-GO & Jataí-GO & Montividiu-GO & Patos de Minas-MG & Uberlândia-MG & Unaí-MG \\
\hline AG8677PRO3 & $6835.45 \mathrm{Ba}$ & $8042 \mathrm{Aa}$ & $9044.69 \mathrm{Ab}$ & $7259.06 \mathrm{Ba}$ & $6232.94 \mathrm{Ca}$ & $4584.83 \mathrm{Da}$ \\
AG8690PRO3 & $6654.62 \mathrm{Ba}$ & $7217.93 \mathrm{Ba}$ & $10386.02 \mathrm{Ab}$ & $6823.6 \mathrm{Bb}$ & $4413.7 \mathrm{Cb}$ & $4039.12 \mathrm{Ca}$ \\
AG9050PRO3 & $7626.7 \mathrm{Ba}$ & $7123.45 \mathrm{Ba}$ & $9274.06 \mathrm{Ab}$ & $8019.55 \mathrm{Ba}$ & $6659.56 \mathrm{Ba}$ & $4684.17 \mathrm{Ca}$ \\
AS1555PRO3 & $7177.44 \mathrm{Ba}$ & $6992.75 \mathrm{Ba}$ & $11066.9 \mathrm{Aa}$ & $6698.56 \mathrm{Bb}$ & $4950.57 \mathrm{Cb}$ & $4744.92 \mathrm{Ca}$ \\
AS1633PRO3 & $7550.42 \mathrm{Ba}$ & $8103.04 \mathrm{Ba}$ & $11016.56 \mathrm{Aa}$ & $7694.71 \mathrm{Ba}$ & $6926.04 \mathrm{Ba}$ & $5242.42 \mathrm{Ca}$ \\
AS1735PRO3 & $7233.17 \mathrm{Ca}$ & $8901.23 \mathrm{Ba}$ & $10499.35 \mathrm{Ab}$ & $8244.63 \mathrm{Ba}$ & $7444.49 \mathrm{Ca}$ & $4638.77 \mathrm{Da}$ \\
AS1757PRO3 & $7691.93 \mathrm{Ba}$ & $7740.68 \mathrm{Ba}$ & $10504.85 \mathrm{Ab}$ & $7694.95 \mathrm{Ba}$ & $6213.48 \mathrm{Ca}$ & $5017.46 \mathrm{Ca}$ \\
AS1780PRO3 & $6957.12 \mathrm{Ba}$ & $8199.75 \mathrm{Ba}$ & $11673.81 \mathrm{Aa}$ & $7699.25 \mathrm{Ba}$ & $4336.32 \mathrm{Cb}$ & $5316.19 \mathrm{Ca}$ \\
DKB290PRO3 & $6860.39 \mathrm{Ba}$ & $8098.8 \mathrm{Ba}$ & $10287.02 \mathrm{Ab}$ & $7540.37 \mathrm{Ba}$ & $4588.21 \mathrm{Cb}$ & $3872.31 \mathrm{Ca}$ \\
DKB310PRO3 & $6639.24 \mathrm{Ca}$ & $7857.57 \mathrm{Ba}$ & $11619.36 \mathrm{Aa}$ & $6365.75 \mathrm{Cb}$ & $6606.31 \mathrm{Ca}$ & $3471.4 \mathrm{Da}$ \\
DKB335PRO3 & $7497.74 \mathrm{Ba}$ & $8453.02 \mathrm{Ba}$ & $10953.68 \mathrm{Aa}$ & $7426.06 \mathrm{Ba}$ & $7616.91 \mathrm{Ba}$ & $5249.38 \mathrm{Ca}$ \\
DKB390PRO3 & $6074.61 \mathrm{Ca}$ & $7684.09 \mathrm{Ba}$ & $10275.59 \mathrm{Ab}$ & $5401.41 \mathrm{Cb}$ & $3531.03 \mathrm{Db}$ & $4702.11 \mathrm{Da}$ \\
H5 & $7008.02 \mathrm{Ca}$ & $8440.97 \mathrm{Ba}$ & $9854.2 \mathrm{Ab}$ & $8036.1 \mathrm{Ba}$ & $5180.27 \mathrm{Db}$ & $4784.87 \mathrm{Da}$ \\
\hline
\end{tabular}

${ }^{1}$ averages followed by distinct letters, uppercase in the row and lowercase in the column, differ from each other by the Scott-Knott test at $5 \%$ probability. 
The Centroid method consists in comparing the values and the Cartesian distance between the genotypes and ideal genotypes, designated as Ideotype, allowing the classification of these as the General adaptability, Specific adaptability to favorable environments, Specific adaptability to unfavorable and Poorly adapted environments (Rocha et al., 2005), as shown in Tables 15 and 16. In 2016 (Table 15), 38\% of the hybrids were classified as General adaptability, indicating the possibility of recommendation for all tested environments. In the same year, $46 \%$ of the hybrids were classified as Specific adaptability to favorable and unfavorable environments and $16 \%$ of them were classified as Poorly adapted. In 2017, the hybrids classified as General adaptability were $38.5 \%$, which indicates the possibility of being recommended for the total of tested environments. $38.5 \%$ of the hybrids were classified as Specific adaptability to favorable and unfavorable environments and $23 \%$ of the hybrids were classified as Poorly adapted. In line with the observed in this research, Faria (2016) using the Centroid method, observed that $72.4 \%$ of the genotypes evaluated in the off season of Minas Gerais in 2016, were classified with general adaptability.

According to Rocha et al. (2005), probability values near or higher than 0.50 indicate good reliability in the genotype groupings in relation to the ideotypes. In this study, the probability values that allowed the classification of the genotypes between the groups ranged from 0.06 to 0.45 in the year 2016 (Table 15) and 0.05 to 0.35 (Table 16).

Table 15. Grain yield and stability and adaptability parameters by the centroid method (Rocha et al., 2005), in 24 genotypes of off season corn cultivated in seven environments in 2016.

\begin{tabular}{|c|c|c|c|c|c|c|}
\hline Genotypes & Average (kg.ha $\left.{ }^{-1}\right)$ & Classification & Prob (I) & Prob (II) & Prob (III) & Prob (IV) \\
\hline 3400RR2 & 4837.79 & $\mathrm{I}$ & 0.33 & 0.20 & 0.26 & 0.18 \\
\hline AG7088PRO3 & 4635.31 & I & 0.30 & 0.21 & 0.27 & 0.20 \\
\hline AG8070PRO3 & 5317.95 & I & 0.35 & 0.16 & 0.31 & 0.16 \\
\hline AG8677PRO3 & 4656.2 & I & 0.31 & 0.27 & 0.20 & 0.19 \\
\hline AG8700PRO3 & 4608.46 & I & 0.30 & 0.28 & 0.20 & 0.20 \\
\hline AS1581PRO & 3839.83 & II & 0.19 & 0.32 & 0.18 & 0.29 \\
\hline AS1656PRO3 & 3902.77 & II & 0.22 & 0.28 & 0.21 & 0.27 \\
\hline AS1777PRO3 & 4780.82 & III & 0.29 & 0.19 & 0.30 & 0.20 \\
\hline DAS2B512PW & 4828.59 & I & 0.33 & 0.23 & 0.23 & 0.19 \\
\hline DAS2B610PW & 4647.16 & I & 0.29 & 0.25 & 0.24 & 0.21 \\
\hline DAS2B688PW & 3775.31 & IV & 0.18 & 0.25 & 0.21 & 0.34 \\
\hline DAS2B810PW & 3969.18 & IV & 0.20 & 0.23 & 0.24 & 0.31 \\
\hline DKB290PRO3 & 4483.84 & III & 0.25 & 0.22 & 0.28 & 0.23 \\
\hline DKB310PRO3 & 4121.51 & II & 0.21 & 0.35 & 0.18 & 0.24 \\
\hline DKB390PRO2 & 3889.03 & II & 0.19 & 0.32 & 0.18 & 0.29 \\
\hline DKB390PRO3 & 3525.23 & IV & 0.16 & 0.29 & 0.17 & 0.35 \\
\hline H1 & 4011.25 & IV & 0.18 & 0.19 & 0.29 & 0.32 \\
\hline $\mathrm{H} 2$ & 4663.26 & III & 0.24 & 0.19 & 0.33 & 0.22 \\
\hline H3 & 3988.98 & II & 0.19 & 0.43 & 0.15 & 0.21 \\
\hline $\mathrm{H} 4$ & 4066.8 & II & 0.20 & 0.35 & 0.17 & 0.26 \\
\hline MG652PW & 4725.48 & I & 0.33 & 0.26 & 0.20 & 0.18 \\
\hline P30F53YHR & 4100.48 & II & 0.24 & 0.28 & 0.22 & 0.25 \\
\hline P3646LEP & 3980.48 & II & 0.20 & 0.31 & 0.19 & 0.28 \\
\hline RIB9110PRO & 4928.45 & $\mathrm{I}$ & 0.37 & 0.28 & 0.17 & 0.16 \\
\hline
\end{tabular}

Class I: High General adaptability (MAXF, maxd); Class II: Specific adaptability to favorable environments (MAXF, Mind); Class III: Specific adaptability to unfavorable environments (Minf, maxd); Class IV: Poorly adapted (Minf, Mind); Class V: High General adaptability (MEDF, medd); Class VI: Specific adaptability to favorable environments (MAXF, medd); Class VII: Specific adaptability to unfavorable environments (MEDF, Maxd); Prob: Probability. 
Table 16. Grain yield and stability and adaptability parameters by the centroid method (Rocha et al., 2005), in 13 genotypes of off season corn cultivated in six environments in 2017.

\begin{tabular}{|c|c|c|c|c|c|c|}
\hline Genotypes & Average (kg.ha $\left.{ }^{-1}\right)$ & Classification & $\operatorname{Prob}(\mathrm{I})$ & Prob(II) & Prob(III) & Prob(IV) \\
\hline AG8677PRO3 & 0.25 & III & 0.20 & 0.31 & 0.23 & \\
\hline AG8690PRO3 & 0.18 & IV & 0.28 & 0.19 & 0.34 & \\
\hline AG9050PRO3 & 0.28 & III & 0.19 & 0.31 & 0.20 & \\
\hline AS1555PRO3 & 0.23 & IV & 0.26 & 0.23 & 0.26 & \\
\hline AS1633PRO3 & 0.50 & I & 0.16 & 0.20 & 0.13 & \\
\hline AS1735PRO3 & 0.51 & I & 0.16 & 0.19 & 0.13 & \\
\hline AS1757PRO3 & 0.35 & I & 0.20 & 0.25 & 0.17 & \\
\hline AS1780PRO3 & 0.25 & II & 0.36 & 0.17 & 0.20 & \\
\hline DKB290PRO3 & 0.20 & II & 0.35 & 0.18 & 0.26 & \\
\hline DKB310PRO3 & 0.29 & I & 0.24 & 0.24 & 0.21 & \\
\hline DKB335PRO3 & 0.54 & I & 0.13 & 0.20 & 0.11 & \\
\hline DKB390PRO3 & 0.14 & IV & 0.22 & 0.17 & 0.44 & \\
\hline H5 & 0.27 & II & 0.29 & 0.21 & 0.22 & \\
\hline AG8677PRO3 & 69.998 .258 & III & 0.25 & 0.20 & 0.31 & 0.23 \\
\hline AG8690PRO3 & 65.891 .633 & IV & 0.18 & 0.28 & 0.19 & 0.34 \\
\hline AG9050PRO3 & 72.312 .458 & III & 0.28 & 0.19 & 0.31 & 0.20 \\
\hline AS1555PRO3 & 69.385 .208 & IV & 0.23 & 0.26 & 0.23 & 0.26 \\
\hline AS1633PRO3 & 77.555 .283 & I & 0.50 & 0.16 & 0.20 & 0.13 \\
\hline AS1735PRO3 & 78.269 .375 & I & 0.51 & 0.16 & 0.19 & 0.13 \\
\hline AS1757PRO3 & 74.772 .242 & I & 0.35 & 0.20 & 0.25 & 0.17 \\
\hline AS1780PRO3 & 73.637 .367 & II & 0.25 & 0.36 & 0.17 & 0.20 \\
\hline DKB290PRO3 & 68.745 .158 & II & 0.20 & 0.35 & 0.18 & 0.26 \\
\hline DKB310PRO3 & 70.932 .675 & I & 0.29 & 0.24 & 0.24 & 0.21 \\
\hline DKB335PRO3 & 78.661 .292 & I & 0.54 & 0.13 & 0.20 & 0.11 \\
\hline DKB390PRO3 & 62.781 .383 & IV & 0.14 & 0.22 & 0.17 & 0.44 \\
\hline H5 & 72.174 .025 & II & 0.27 & 0.29 & 0.21 & 0.22 \\
\hline
\end{tabular}

Class I: High General adaptability (MAXF, maxd); Class II: Specific adaptability to favorable environments (MAXF, Mind); Class III: Specific adaptability to unfavorable environments (Minf, maxd); Class IV: Poorly adapted (Minf, Mind); Class V: High General adaptability (MEDF, medd); Class VI: Specific adaptability to favorable environments (MAXF, medd); Class VII: Specific adaptability to unfavorable environments (MEDF, Maxd).

In order to infer about the stability of the genotypes by the AMMI analysis (Zobel et al., 1988), the first two principal components (CP1, CP2) were represented in the Cartesian plane, for the years 2016 and 2017 (Figures 1 and 2, respectively).

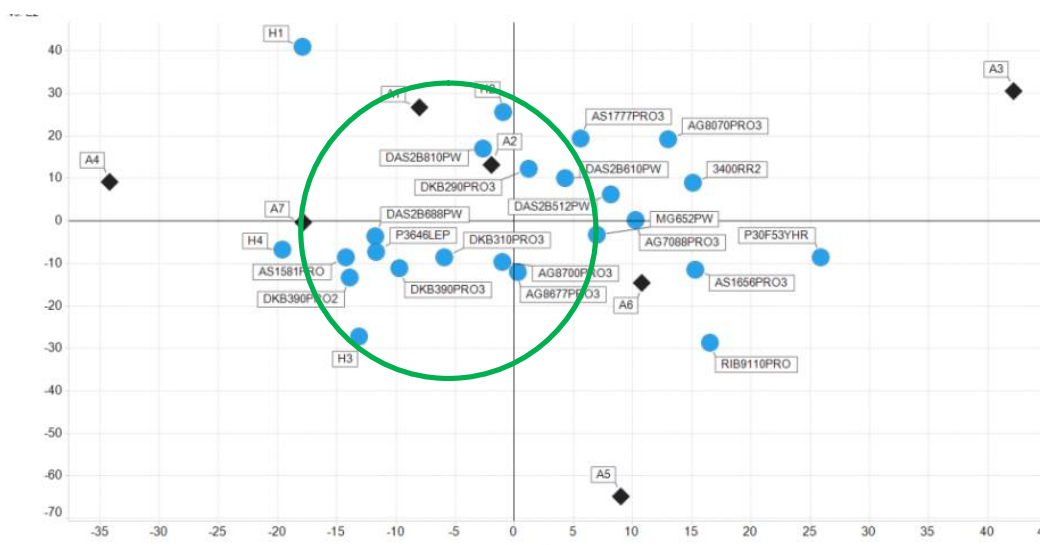

Figure 1. Plotting of the scores of the first two main components, according to the model AMMI 2 for grain yield, for 24 genotypes of off season corn in 2016. 


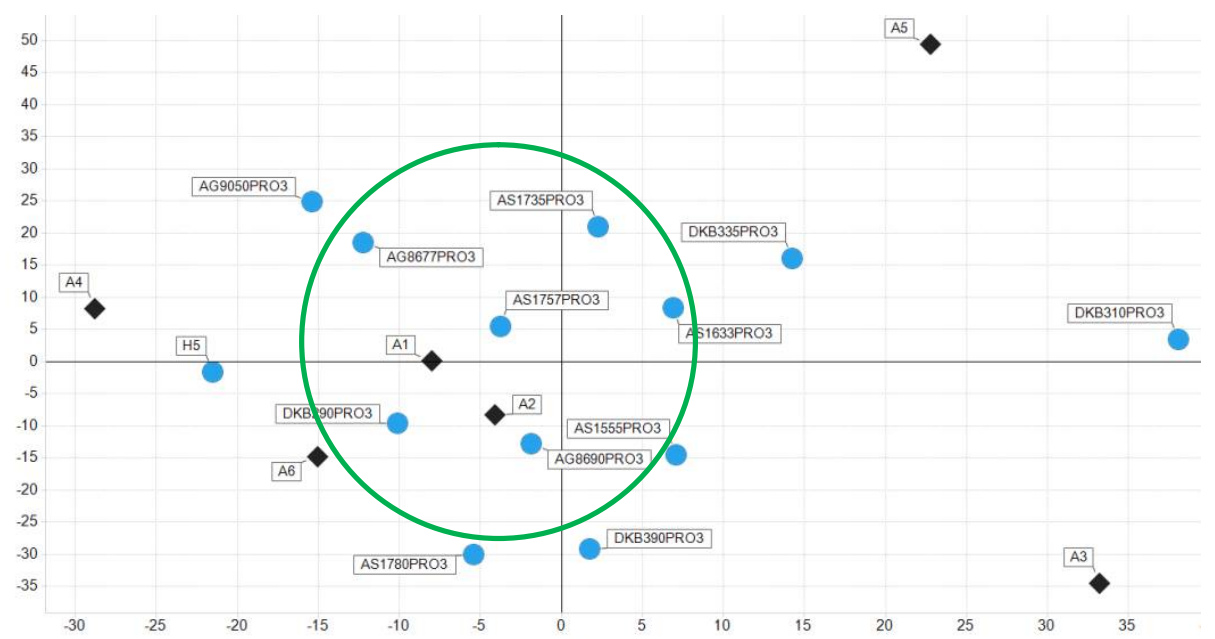

Figure 2. Plotting of the scores of the first two main components, according to the model AMMI 2 for grain yield, for 13 genotypes of off season corn in 2017.

For the AMMI analysis, the first two main components (CP1 and CP2) explained $73 \%$ of the variation due to the interaction $\mathrm{G} \times \mathrm{E}$ in the year 2016 and $78.9 \%$ of the variation due to the interaction $\mathrm{G} x \mathrm{E}$ in the year 2017. According to Pereira et al. (2009), the first main components should explain above $70 \%$ of the sum of the squares of the interaction, to be considered satisfactory. When evaluating 29 corn hybrids in the off season of 2016, Faria (2016) observed values of $72.6 \%$ of CP1 and CP2 accumulated.

The interpretation of the stability by the AMMI method was performed from the distance of the representative points of the hybrids and environments to the zero score (Figure 1 and Figure 2). Thus, the shortest distance indicates greater stability (Duarte and Vencovsky, 1999).

The most distant hybrids of the axis, are those that contributed little to the interaction G x E total and were considered more stable and with general adaptability, because they interact less with the environments (Chaves, 2001). For the year 2016 (Figure 1), 2 of the hybrids that are positioned closest to the origin of the axes and were, therefore, classified as more stable and of general adaptability, are among the 5 most productive hybrids, for the year 2017 (Figure 2), this same proportion was 3 of the hybrids classified as more stable and of general adaptability and more productive. In 2016 (Figure 1), the most traditional environments were those that contributed to the $G$ $\mathrm{x}$ E interaction, while for the year 2017 (Figure 2), there was a greater contribution of non-traditional region environments to the planting of off season corn in the interaction $\mathrm{G} \times \mathrm{E}$, since these were farther away from the origin of the axes.

The results showed that the hybrid AG8700PRO3 showed high grain yield, wide adaptation and high stability in the 2016 crop, already in the harvest of 2017 the same occurred for the hybrid AS1757PRO3. 


\section{DISCUSSION}

In the two years of testing evaluated in this study, the experimental precision was classified as medium to high through the coefficient of variation, which indicates the experimental precision quality. Experiments with low coefficients of variation, or high precision, are desired by the breeders, since they provide the obtaining of estimates of genetic parameters more reliable, or accurate, which are important in decision making process of the breeding program (Cargnelutti Filho et al., 2012). According to PimentelGomes (1990), a CV $(\%)$ is considered low and with high precision $(<10 \%)$; medium $=(10$ to $20 \%)$; high (20 to $30 \%)$; too high ( $>30 \%)$.

The coefficients of genotypic determination that express the proportion of phenotypic variability attributed to genetic causes were $58.54 \%$ for 2016 and $31.04 \%$ for 2017 (Tables 5 and 6), and therefore, of medium magnitude for the character grain production. According to Cruz et al. (2012), the genotypic determination coefficient is considered of high magnitude when it is above $70 \%$.

The occurrence of $\mathrm{G} \times \mathrm{E}$ interaction is indicative of the differential behavior of the genotypes, in relation to grain yield, with environmental oscillation. In this context, the study of $\mathrm{G} \times \mathrm{E}$ interaction becomes important to determine its nature. Most quantitative traits, such as yield, are polygenic in nature and highly influenced by the environment. The $\mathrm{G} \times \mathrm{E}$ interaction strongly influences the expression of these quantitative traits (Schmildt et al., 2011).

Grain yield is one of the most highly valued traits by breeding programs. In general, one applies selection for traits indirectly related to yield; towards the end of the program, a higher selection index is applied to increase effectiveness in obtaining high yielding genotypes. The yield expression is controlled by quantitative or polygenic traits; i.e. it depends on the action of many genes. When the selective pressure is high at the beginning of the breeding program, some heterozygous inbred lines can be eliminated, affecting the number of superior lines reaching final trials.

One of the methods used in the evaluation of adaptability and stability is a method based on simple linear regression of Eberhart and Russel (1966). This method also allows one to classify the environments as favorable and unfavorable according to the environmental index. High adaptability and stability hybrids have better agronomic performance and commercial viability (Busanello, et al 2015)

When this index results in a negative value, it indicates that the environment is unfavorable and when the index is positive, the environment is classified as favorable. Favorable sites occur due to the influence of the environment, which, in the case of corn crop, probably went through some biotic or abiotic stress. Faria (2016) classified environments in favor of evaluating hybrids in the off season of Minas Gerais.

The Eberhart and Russel Method (1966) also allows the identification of genotypes with specific adaptation to favorable environments (B1 > 1) and unfavorable (B1 < 1). According to this method, the ideal genotype is the one that presents broad adaptation (B1 = 1) and high stability (variance of the deviations from the null regression). Regarding the simultaneous analysis of the adaptability and stability parameters ( $\beta 1 \mathrm{i}$ and $\Sigma 2$ di) obtained by this method, it was found that the majority of the hybrids showed high predictability of behavior and wide adaptability. Acording to Busanelo et al. (2015), in a study of stability and adaptability of corn hybrids in southern Brazilian regions, the yield magnitude of these 
hybrids is influenced positively by the ability to take advantage of predictable stimuli of environments.

This result confirms Montividiu as a favorable region for hybrid potential expression, reaffirming its position as a traditional region for off season corn cultivation. Duvick (2005) affirms that changes in cultural practices have been responsible for a significant portion of maize yield gains. This could be related to timeliness of planting and selection of adapted regions.

Environmental stratification analysis also allows you to make decisions about discards of environments, when there are technical problems or shortage of resources, and identify groups of environments where the $\mathrm{G} \times \mathrm{E}$ interaction may not be significant for the set of available genotypes (Cruz et al., 2012).

\section{CONCLUSIONS}

The genotype-environment interaction for grain yield in corn hybrids cultivated in the off season is of a complex type. In the years 2016 and 2017, there was high grain yield of corn in the corn off season in the environments of Jataí-GO and Montividiu-GO, both considered as traditional regions in the off season. In the off season of 2016, the hybrids DAS2B512PW, MG652PW and AG8700PRO3 showed high grain yield, wide adaptation and high stability. In the off season of 2017, the hybrids AS1633PRO3, AS1757PRO3 and DKB335PRO3 showed high grain yield, wide adaptation and high stability.

\section{REFERENCES}

Busanello C, Souza VQ, Oliveira AC, Nardino M, et al. (2015). Adaptability and stability of corn hybrids in southern Brazilian environments. J. Agric. Sci. 7: 228-235.

Cargnelutti Filho A, Marchesan E, Silva LS and Toebe M (2012). Medidas de precisão experimental e número de repetições em ensaios de genótipos de arroz irrigado. Pesquisa Agr. Brasil. 47: 336-343.

Carneiro PCS (1998). Novas metodologias de análise da adaptabilidade e estabilidade de comportamento. Doctoral thesis, Universidade Federal de Viçosa, Viçosa.

Chaves LJ (2001). Interação de genótipos com ambientes. In: Recursos genéticos e melhoramento de plantas (Nass LL, Valois ACC, Melo IS, Valadares-Inglis MC, eds.). Fundação MT, Rondonópolis, 673-713.

CONAB (Companhia Nacional de Abastecimento) (2017). Acompanhamento da safra brasileira: grãos - v.4 - SAFRA 2016/17 - N.4 - Quarto levantamento. CONAB, Brasília, 162p. Available at:[http://www.conab.gov.br/OlalaCMS/uploads/arquivos/17_01_11_11_30_39_boletim_graos_janeiro_2017.pdf]. Acessed January, 14, 2017.

Cruz CD (1997). Programa GENES: aplicativo computacional em genética e estatística (software). Imprensa Universitária, Viçosa.

Cruz CD, Regazzi AJ and Carneiro PCS (2012). Modelos biométricos aplicados ao melhoramento genético. 4th edn. Imprensa Universitária, Viçosa.

Cruz CD and Castoldi FL (1991). Decomposição da interação genótipo x ambiente em parte simples e complexa. Rev. Ceres. 38: 422-430.

Duarte JB and Vencovsky R (1999). Interação genótipos $x$ ambientes: uma introdução à análise AMMI. Série Monografias. 9 edn. Sociedade Brasileira de Genética, Ribeirão Preto.

Duvick DN (2005). The contribution of breeding to yield advances in maize (Zea mays L.). In: Advances in Agronomy. Iowa State University, Ames.

Eberhart SA and Russel WA (1966). Stability parameters for comparing varieties. Crop Sci. 6: 36-40.

EMBRAPA (Empresa Brasileira de Pesquisa Agropecuária) (2015). MILHO. Available at [http://www.cnpms.embrapa.br/publicacoes/milho_1_ed/mercado.htm]. Accessed May 10, 2016.

Faria SV (2016). Adaptabilidade e Estabilidade de Híbridos Comerciais de Milho pelos Métodos de Eberhart \& Russell, Centróide, AMMI e Modelos Mistos. Master's thesis, Universidade Federal de Viçosa, Viçosa.

Farinelli R, Penariol FG, Bordin L, Coicev L, et al. (2003). Desempenho agronômico de cultivares de milho nos períodos de safra e safrinha. Bragantia. 62: 235-241. 
Figueiredo AG, Renzo Pinho GV, Silva HD and Balestre M (2014). Application of mixed models for evaluating stability and adaptability of maize using unbalanced data. Euphytica. 202: 393-409.

Fritsche-Neto R, Miranda GV, DeLima RO and Souza HN (2010). Factor analysis and SREG GGE biplot for the genotypexenvironment interaction stratification in maize. Cienc. Rural. 40: 1043-1048.

IBGE. Instituto Brasileiro de Geografia e Estatística (2015). Resultados da Produção Agrícola Municipal. Available at [ https://ww2.ibge.gov.br/home/presidencia/noticias/imprensa/ppts/00000027422109112016210223405721.pdf]. Accessed October 30, 2018.

Landau EC, Hirsch A, Cruz JC, Duarte JO, et al. (2012). Áreas de concentração da produção de milho no Brasil entre 2008 e 2010. In: Boletim de Pesquisa e Desenvolvimento 58. Embrapa Milho e Sorgo, Sete Lagoas.

Lin CS and Binns MR (1988). A method of analyzing cultivar x location x year experiment: a new stability parameter. Theor. Appl. Genet. 76: 425-430.

Martinelli AP (2013). Métodos AMMI, GGE Biplot, REML/BLUPE análise de fatores na estabilidade e estratificação de ambientes de safrinha para seleção de híbridos de milho. Master's thesis, Universidade Federal de Uberlândia, Uberlândia.

Moraes DF and Brito CH (2011). Análise de possível correlação entre as características morfológicas do colmo do milho e o acamamento. Universidade Federal de Uberlândia. Available at [http://www.seer.ufu.br/index.php/horizontecientifico/article/viewFile/4079/3038\%3E.\%20Acesso\%20em:\%2026/0 1/2014]. Accessed February 6, 2019.

Pereira HS, Melo LC, Faria LC, Del Peloso MJ, et al. (2009). Adaptabilidade e estabilidade de genótipos de feijoeirocomum com grãos tipo carioca na Região Central do Brasil. Pesq. Agropec. Bras. 44: 29-37.

Pimentel-Gomes F (1990). Curso de estatística experimental.13.edn. Nobel, Piracicaba.

Ramalho MAP, Santos JB, Pinto CABP, Souza EA, et al. (2012). Genética na agropecuária. Universidade Federal de Lavras, Lavras.

Rocha RB, Muro-Abad JI, Araújo EF and Cruz CD (2005). Avaliação do método centróide para estudo de adaptabilidade ao ambiente de clones de Eucalyptus grandis. Ciênc. Florest. 15: 255-266.

Schmildt ER, Nascimento AL, Cruz CD and Oliveira JAR (2011). Avaliação de metodologias de adaptabilidade e estabilidade de cultivares milho. Acta Sci. Agron. 33: 51-58.

Silva PR, Bisognin DA, Locatelli AB and Storck L (2014). Adaptability and stability of corn hybrids grown for high grain yield. Acta Sci. Agron. 36: 175-181.

Silva AG, Francischini R and Martins PDS (2015). Desempenhos agronômico e econômico de cultivares de milho na safrinha. Rev. Agrarian. 8: 1-11.

Tsunechiro A and Godoy RCB (2001). Histórico e perspectivas do milho safrinha no Brasil. In: A cultura do milho safrinha (Shioga PS, Barros ASR, eds.). IAPAR, Londrina.

UFLA (Universidade Federal de Lavras) (2000). Estabilidade (software): versão 3.0. Ufla-DEX, Lavras.

Zobel RW, Wright MJ and Gauch HG (1988). Statistical Analysis of a Yield Trial. Agron. J. 80: 388-393. 